\title{
Demonstration Method Drawing Tutorial for Autism Student
}

\author{
Budiman*, Anne Nurfarina \\ Widyatama University, Indonesia
}

Copyright $\subseteq 2019$ by authors, all rights reserved. Authors agree that this article remains permanently open access under the terms of the Creative Commons Attribution License 4.0 International License

\begin{abstract}
Autism children in Indonesia rarely get access like other students because of their differences in learning and adaptation to surrouding environment. This paper will share authors' experience in developing teaching method on still life drawing technique towards autism student and their experiments of similar method towards normal students. The results are still life drawing teaching techniques towards autism students requires gradual confidence building for their ability to draw through provided on site how-to-draw experience and drawing examples to be copied. Surprisingly, similar method can be applied towards normal students.
\end{abstract}

Keywords Demonstration Method, Drawing Tutorial, Autism

\section{Introduction}

Drawing is a mandatory skill that must be possessed by every student or student in the study program in Fine Arts, Craft, and Design even though the quality achievement is relative. In 2017, the number of Visual Communication Design study programs in all universities throughout Indonesia amounted to 91 (source: DIKTI).

Students in the study program input their backgrounds differently, some have not been able to draw because they rarely draw, some just start drawing, and some often draw. Flying hours or often drawing is what distinguishes students from drawing or not.

The input of students in the study program usually has different ability or drawing skills, can be divided into three categories, namely; (1) students in public schools or colleges with a ratio between registrants and those who receive it are very high usually have a standard of ability in drawing above the average because each student / student flying hours (drawing exercises) is high. (2) students at public or private schools or colleges with the ratio between registrants and those who are being accepted are usually the ability to draw it is also being caused because every student / student flight hours (drawing exercises) are usually they are active in drawing only one year or while participating drawing tutoring. (3) students in public or private schools or colleges with a ratio between registrants and those received are usually small in the ability to draw is also small because every student flying hours (drawing exercises) below the average they usually just want to start drawing.

Of the three largest input level drawing skills faced by students / students of the fine arts study program, craft, and design are low drawing skills / competencies (Khan and Ali, 2017; Nuryati, 2018; Udanoh and Zouria, 2018; Jabarullah and Hussain, 2019). This creates obstacles for each study program, especially for teachers or drawing lecturers.

\section{The Process of Drawing Demonstration Methods}

In this case, the researcher is an illustration lecturer at two different institutions, namely (1) students of special treatment classes with autism at the Art Therapy Center Widyatama and (2) students of the Graphic Design Study Program at Widyatama University. Furthermore, the learning method applied by researchers to this problem is the demonstration method. Demonstration method is a method of teaching by demonstrating goods, events, rules, and the sequence of carrying out an activity, either directly or through the use of teaching media that are relevant to the subject matter or the material being presented (Muhibbin Shah, 2000; Spathopoulou and Papakonstantinidis, 2017; Aslan Efe and Efe, 2018; Önder, 2018). 


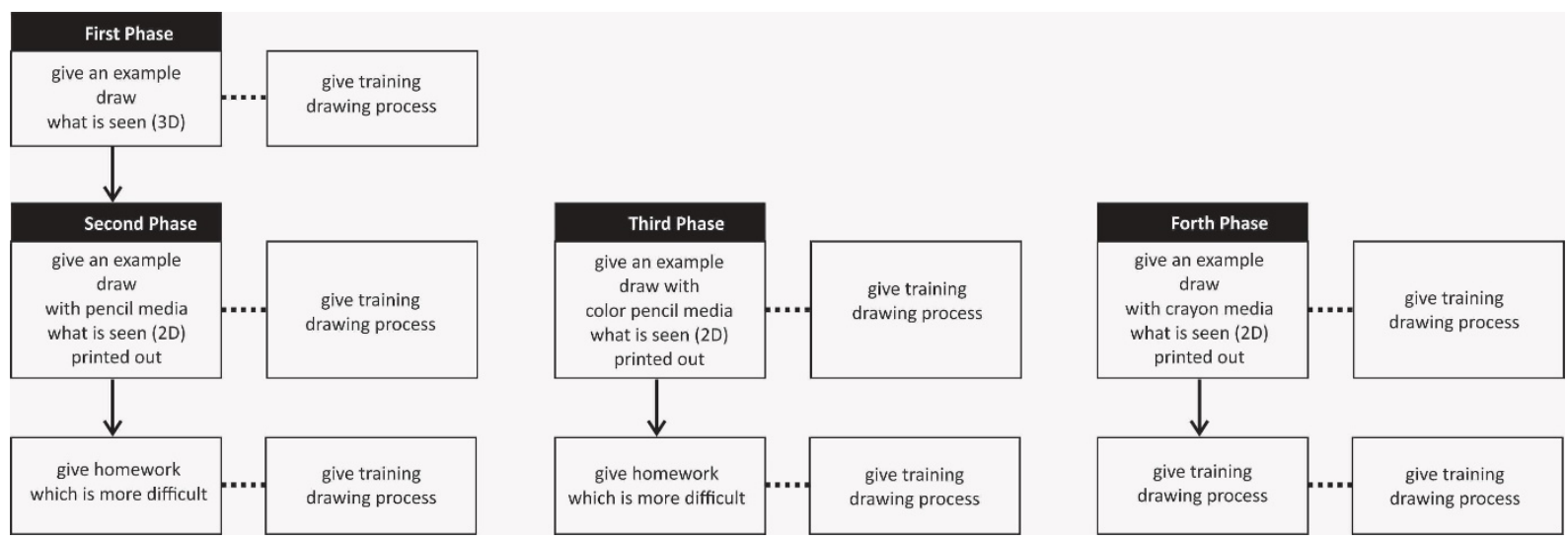

Source: budiman, 2017

Chart 1. The process of drawing a demonstration method

\subsection{Chart Explanation}

\subsubsection{First Phase}

Students are given the task of drawing directly objects that have been prepared in front of them with a pencil drawing tool, then the lecturer gives an example of how to draw it to completion, then the students mimic the drawing activities according to the example of the stage.

Lecturers supervise and train the student drawing process.

\subsubsection{Second Phase}

Students are given the task of drawing directly by looking at the sample image on the paper print out with a pencil drawing tool, then the lecturer gives an example of the process of drawing it to completion, then the student mimics the drawing activity according to the example of the stage.

Lecturers supervise and train the student drawing process.

\subsubsection{Third Phase}

Students are given the task of drawing directly by looking at the sample image on the print out paper (drawing objects are more difficult levels) with a colored pencil drawing tool. Then the lecturer gives an example of how to draw it until it is finished, then the student mimics the drawing activity according to the example of the previous step.

Lecturers supervise and train the student drawing process.

\subsubsection{Forth Phase}

Students are given the task of drawing directly by looking at the sample image on the print out paper with a crayon drawing tool, then the lecturer gives an example of how to draw it until it is finished, then the student mimics the drawing activity according to the example stage.

Lecturers supervise and train the student drawing process.

\section{Implementation of the Drawing Demonstration Method}

\subsection{Implementation of Autism Art Therapy Center Students}

The background of the student's drawing work on autism special treatment is always typical, that is, it likes only on certain objects with pen or marker drawing tools, the previous problem is that it cannot draw with shading techniques and various objects.
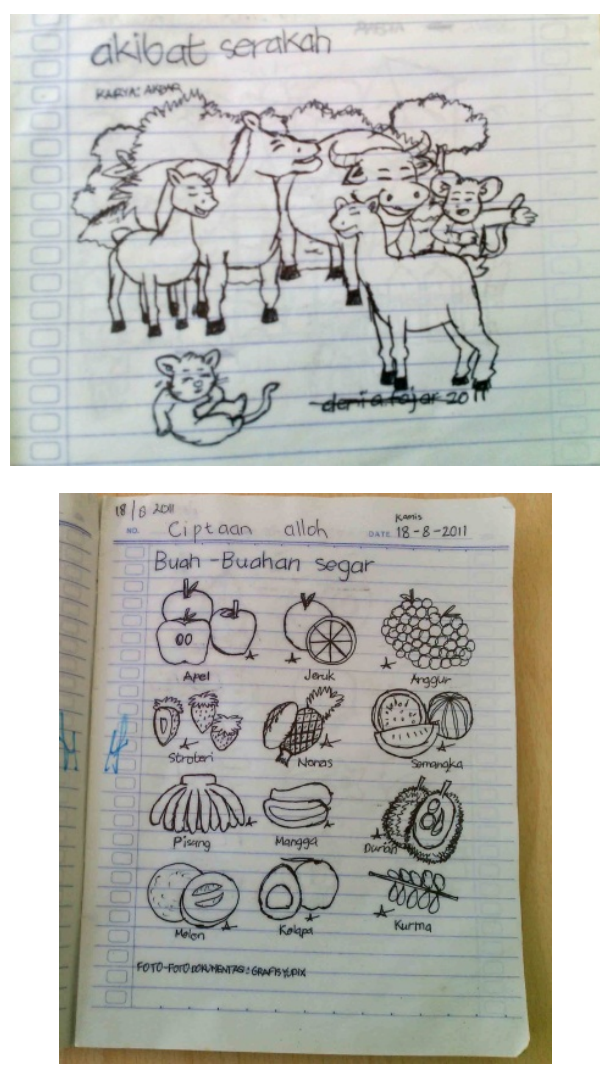

Source: personal documentation

Figure 1. Akbar's work, before becoming a student of Art Teraphy Widyatama 
To introduce new things to autistic students is not easy, it needs to be familiar with the atmosphere; like greeting pleasantly according to his favorite / hobby. After being conditioned, the flight is just to draw learning material. Ask for 3 alternative objects that are drawn, so the autistic student will choose those who are considered capable of drawing them. Then give an example of how to draw it to completion. Give the task to do the drawing activities as exemplified earlier. In this case the object in the picture is an apple, when it is finished drawing according to the command. Then add another object and give an example to draw it and so on.
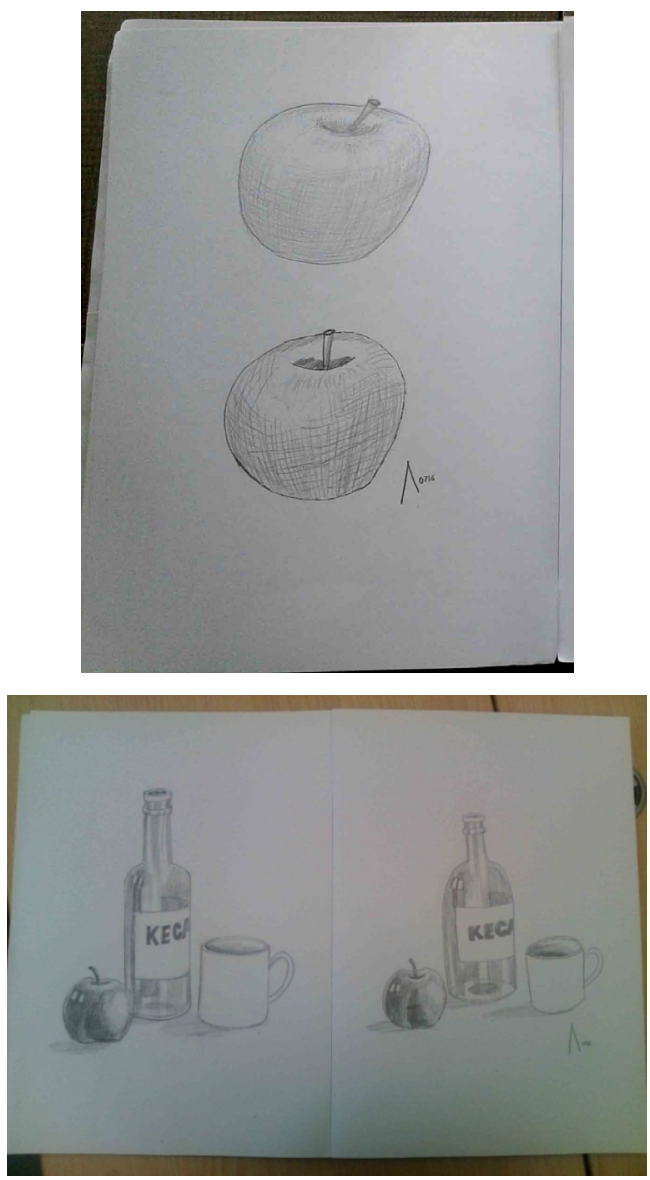

Source: personal documentation

Figure 2. Akbar works, A4 paper size pencil technique
Give a diverse task and if students have started to be able to shade the shade then no longer be given examples of shading ways so that autistic students independently shaded.
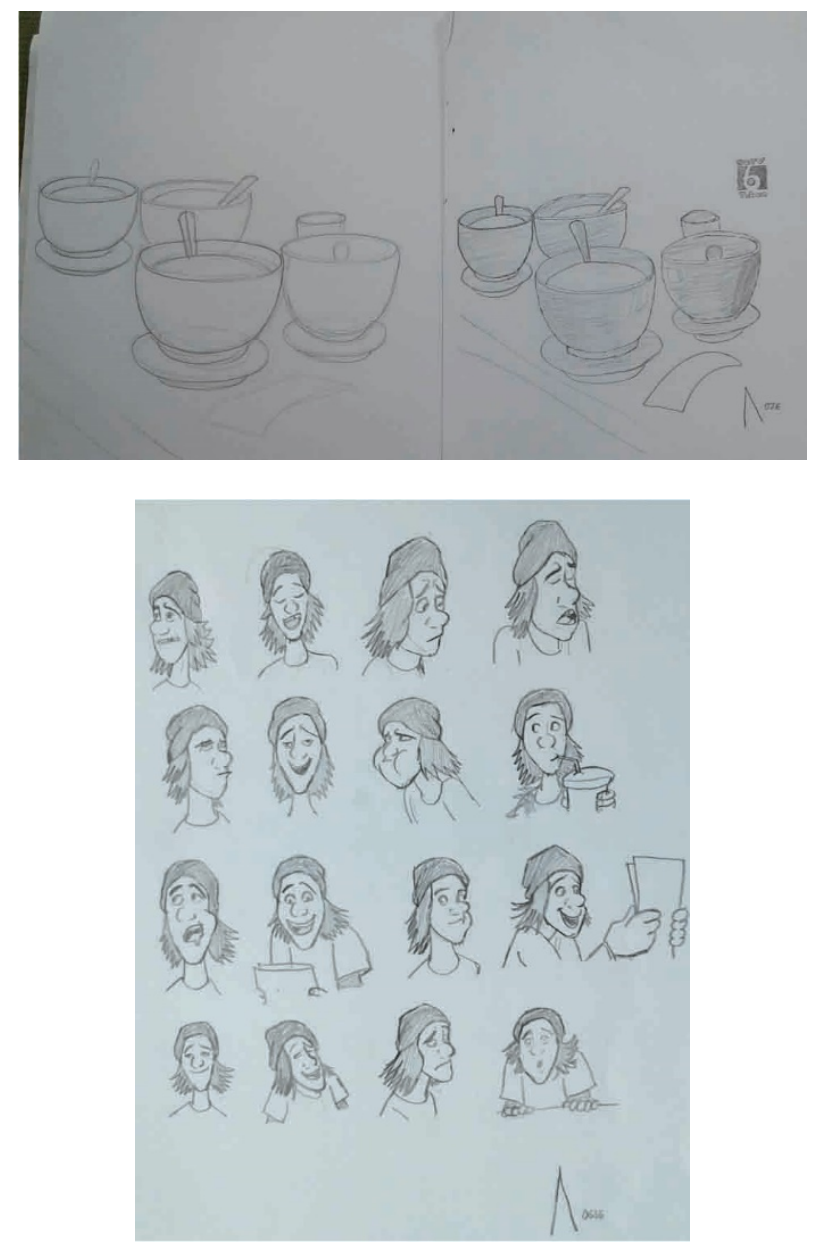

Source: personal documentation

Figure 3. Akbar work, A3 paper size pencil technique

Give the picture drawing with the image object that continues to increase the level of difficulty, as in the example picture below, the object of the Tin tin comic in which there are various objects such as; anatomy, character with diverse facial features, plants, buildings and so on. 



Source: personal documentation

Figure 4. Akbar work, A3 paper size pencil technique

If you have achieved Learning Outcomes, then assign the task to the next step, namely to different objects and drawing tools, like the example below.
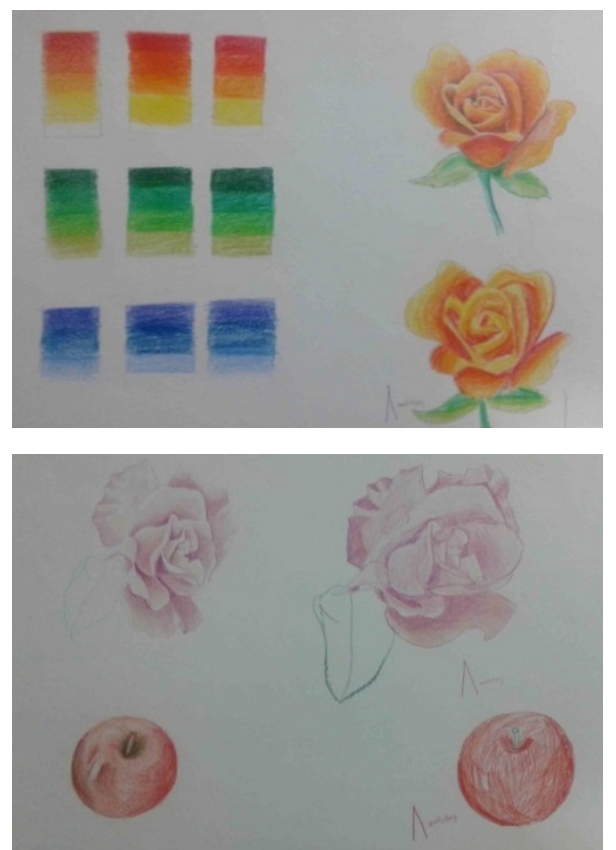

Source: personal documentation

Figure 5. Akbar work, A3 paper size color pencil technique

Give examples of how to draw gradations using various colors, then give the task of drawing gradations as exemplified (Ahmed, Umrani, Qureshi \& Sarmad, 2018; Ali \& Haseeb, 2019; Haseeb, Abidin, Hye, \& Hartani, 2018; Haseeb., 2019; Suryanto, Haseeb, \& Hartani, 2018). After you can draw a color gradation, then describe how to create objects (for example flowers) with gradation techniques according to the sample images from the print out paper provided. Next assign tasks with other objects again (for example apples) and so on until students can independently draw mimics directly from the sample image of the print out results. After being able to master independently, increase the ability to color it with objects that are harder and larger in paper size, like the example below.

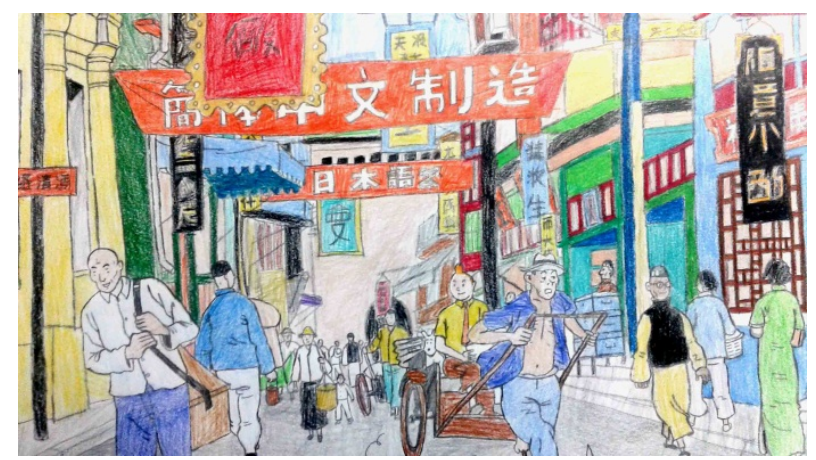

Source: personal documentation

Figure 6. Akbar works, the size of $\mathrm{A} 2$ color pencil technique 
If you have been given a task that is always in accordance with the level of progress, then assign tasks with another object with different gradation and drawing styles, like the example below.

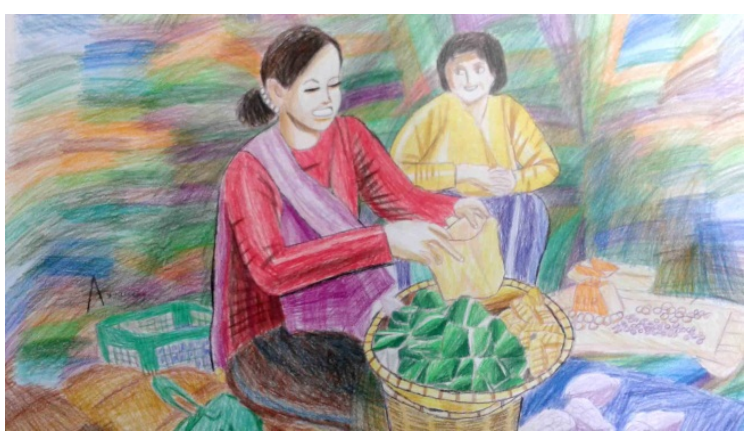

Source: personal documentation

Figure 7. Akbar Work, A2 paper size of colored pencil technique

If the pencil technique, color pencil has mastered, then give the drawing technique, using crayon in a sequence like the previous stages.
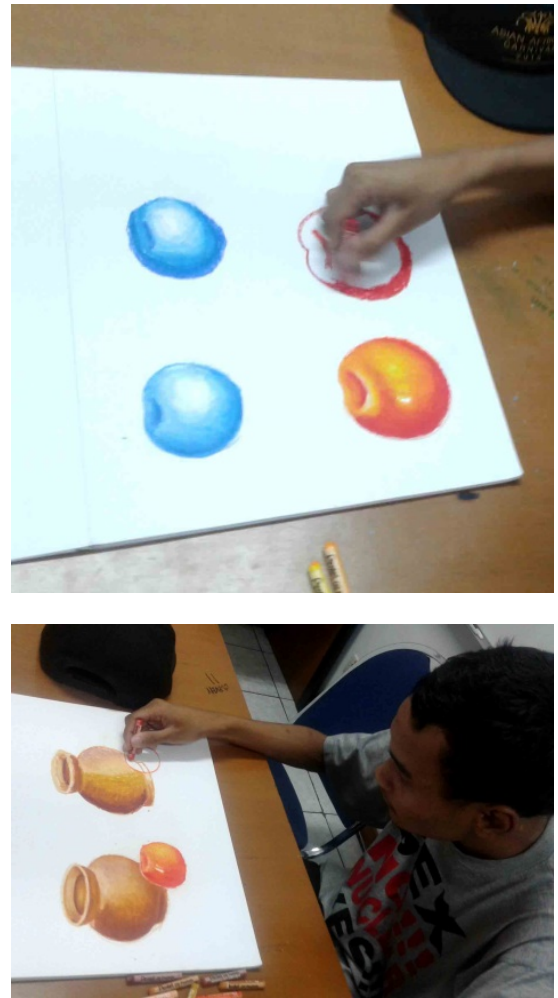

Source: personal documentation

Figure 8. Akbar work, A3 paper size crayon technique

\subsection{Implementation of students in the Graphic Design Study Program}

In students in the Graphic Design Study Program the mastery level of drawing is quite low at around $15 \%$ which is good for drawing from each class. Obstacles faced by students usually lack confidence in their abilities, especially if they have been given a human drawing assignment. But given the drawing demonstration method that was applied to autistic students. Students become able to follow the drawing process. The task given is to draw portrait with trace techniques on A1 size with charcoal drawing tools (Wang and Yang, 2018; Obiero, 2018).

The first stage the researcher gave an example of how to draw the right eye with a slow process so that students could see and follow it, then the students drew their left eye with the way that was exemplified earlier. Next the researchers gave examples of certain parts of the head such as; part of the nose (try about $10 \%$ of each part that is exemplified), some hair, some clothes (cloth). from this method students can follow until the end and after finishing, usually students do not believe in their abilities. So that there was confidence that he could draw (produce works).So that, with the existence of strong self-confidence makes the beginning to work further. And the next task students draw portraits independently (not given examples), the researchers just watched.



Source: personal documentation

Figure 9. The process of drawing Gartila's work, A1 paper size charcoal technique



Source: personal documentation

Figure 10. The atmosphere of drawing, A1 paper size charcoal technique 



Source: personal documentation

Figure 11. Examples of portrait works, A1 paper size charcoal techniques

\section{Conclusions}

Based on observations, trials, and analysis of the Drawing Demonstration Method, the researcher gets the following conclusions (Jabarullah and Hussain, 2018):

1. This method can be successful if taught in a comfortable (conducive) condition, so that students draw happily.

2. Students can do drawing activities with concentration if the objects are drawn according to their abilities.

3. Give extra time / extra time to the drawing process (exceeding the SKS time) in the finishing process because if suspended / paused the concentration is usually disturbed.

4. So students with low drawing skills can be overcome in Allah.

\section{REFERENCES}

[1] Aslan Efe, H., \& Efe, R. (2018). The Relationship between Academic Procrastination Behaviors of Preservice Science Teachers and Their Attitudes toward Social Media. Journal of Education and e-Learning Research, 5(2), 102-109.

[2] Aunurrahman. 2008. Belajar dan Pembelajaran. Bandung: Alfabeta.

[3] Iskandar Agung. 2012. Penelitian Tindakan Kelas. Jakarta: Bestari Buana.

[4] Jabarullah, N.H. and Hussain, H.I. (2018) Comparison of Higher TVET Education and 'Normal' Academic Education: The Determinants of Electrical Engineering Students' Performance, International Journal of Engineering \& Technology, 7 (4.29), 82-85.

[5] Jabarullah, N.H. and Hussain, H.I. (2019) The Effectiveness of Problem-Based Learning in Technical and Vocational Education in Malaysia, Education + Training, https://doi.org/10.1108/ET-06-2018-0129.

[6] Khan, S. N., \& Ali, E. I. E. (2017). The moderating role of intellectual capital between enterprise risk management and firm performance: A conceptual review. American Journal of Social Sciences and Humanities, 2(1), 9-15.

[7] Nurhayani rustamah, dkk. 2010. Materi dan Pembelajaran IPA SD. Jakarta: Universitas Terbuka.

[8] Nuryati, I. D. (2018). Effectiveness of PBL through Concept Map to Improve Problem Solving Skills of Primary School Students. International Journal of Educational Technology and Learning, 2(2), 41-47.

[9] Obiero, J. (2018). The Relationship between Achievement Motivation and Mathematic Performance Amongst Female Learners and in Selected Urban Girls Secondary Schools in Kenya. Global Journal of Social Sciences Studies, 4(1), 23-29.

[10] Önder, M. (2018). Contribution of Plays and Toys to Children's Value Education. Asian Journal of Education and Training, 4(2), 146-149.

[11] Rusman. 2011. Model-Model Pembelajaran. Bandung: Rajawali Pers

[12] Sardiman. 2012. Interaksi dan Motivasi Belajar Mengajar. Jakarta: Rajawali

[13] Soli Abimanyu, dkk. 2008. Strategi Pembelajaran 3 SKS. Jakarta: Direktorat Jendral Pendidikan Tinggi Departeman Pendidikan Nasional.

[14] Spathopoulou, F., \& Papakonstantinidis, S. (2017). Culture as a parameter in assessing students' performance. Humanities and Social Sciences Letters, 5(3), 72-78.

[15] Suharsimi Arikunto. 2010. Penelitian Tindakan. Yokyakarta: Aditya Media.

[16] Udanoh, M. U., \& Zouria, A. (2018). Using Gender 
Inequality to Predict the Rate of African Women Entrepreneurship. International Journal of Emerging Trends in Social Sciences, 3(1), 17-28.

[17] Wang, K., \& Yang, Z. (2018). The Research on Teaching of Mathematical Understanding in China. American Journal of Education and Learning, 3(2), 93-99.

[18] Wayne Enstice and Melody Peters. 1996. Drawing, Space, Form, and Expression. Prentice Hall, Upper Saddle River, New Jersey.

[19] Pourkhani, A., Abdipour, K., Baher, B \& Moslehpour, M. (2019). The impact of social media in business growth and performance: A scientometrics analysis. International Journal of Data and Network Science, 3(3), 223-244.

[20] Ahmed, U., Umrani, W. A., Qureshi, M. A., \& Samad, A. (2018). Examining the links between teachers support, academic efficacy, academic resilience, and student engagement in Bahrain. INTERNATIONAL JOURNAL OF ADVANCED AND APPLIED SCIENCES, 5(9), 39-46.

[21] Ali, A., \& Haseeb, M. (2019). Radio frequency identification (RFID) technology as a strategic tool towards higher performance of supply chain operations in textile and apparel industry of Malaysia. Uncertain Supply Chain Management, 7(2), 215-226.

[22] Haseeb, M., Abidin, I. S. Z., Hye, Q. M. A., \& Hartani, N. H. (2018). The Impact of Renewable Energy on Economic Well-Being of Malaysia: Fresh Evidence from Auto Regressive Distributed Lag Bound Testing Approach. International Journal of Energy Economics and Policy, 9(1), 269-275.

[23] Suryanto, T., Haseeb, M., \& Hartani, N. H. (2018). The Correlates of Developing Green Supply Chain Management Practices: Firms Level Analysis in Malaysia. International Journal of Supply Chain Management, 7(5), 316. 